\title{
Millicurie per Liter
}

National Cancer Institute

\section{Source}

National Cancer Institute. Millicurie per Liter. NCI Thesaurus. Code C71174.

A unit of volumetric radioactivity concentration defined as a concentration of a

radionuclide with an activity equal to one thousandth of a curie per unit volume equal to one liter. 